Article

\title{
Microstructure and High-Temperature Wear Performance of FeCr Matrix Self-Lubricating Composites from Room Temperature to $800{ }^{\circ} \mathrm{C}$
}

\author{
Gongjun Cui ${ }^{1,2, *}$, Yanping Liu ${ }^{1,2}$, Guijun Gao ${ }^{1,2}$, Huiqiang Liu ${ }^{1,2}$ and Ziming Kou ${ }^{1,2}$ \\ 1 College of Mechanical and Vehicle Engineering, Taiyuan University of Technology, Taiyuan 030024, China; \\ yanpingliutyut@sina.com (Y.L.); guijungao333@163.com (G.G.); huiqiang1990@163.com (H.L.); \\ kzmingtyut@163.com (Z.K.) \\ 2 National-Local Joint Laboratory of Mining Fluid Control Engineering, Taiyuan 030024, China \\ * Correspondence: cuigongjun@tyut.edu.cn; Tel.: +86-351-6018949; Fax: +86-351-6018949
}

Received: 13 November 2019; Accepted: 16 December 2019; Published: 20 December 2019

check for updates

\begin{abstract}
FeCr}$ matrix high-temperature self-lubricating composites reinforced by $\mathrm{Mo}, \mathrm{Ag}$, and $\mathrm{CuO}$ were fabricated by the powder metallurgy technique. The tribological behaviors of composites were studied at temperatures up to $800{ }^{\circ} \mathrm{C}$. The $\mathrm{CuO}$ content was optimized according to the tribological results. Mo showed an obvious lubricating effect when it converted into $\mathrm{MoO}_{3}$. The bimetallic oxide system formed high-temperature solid lubricants with low shear strength. $\mathrm{CuO}$ reacted with $\mathrm{MoO}_{3}$ and formed $\mathrm{CuMoO}_{4}$ and $\mathrm{Cu}_{3} \mathrm{Mo}_{2} \mathrm{O}_{9}$. The composites showed an increase in the friction coefficient with the increase of $\mathrm{CuO}$. However, the wear rates decreased with the increase of $\mathrm{CuO}$. The critical threshold at which there was a transition of friction coefficients and wear rates from room temperature (RT) to $800{ }^{\circ} \mathrm{C}$ was $10 \mathrm{wt} . \% \mathrm{CuO}$. The $\mathrm{Fe}(\mathrm{Cr})-14 \% \mathrm{Mo}-10.5 \% \mathrm{Ag}-10 \% \mathrm{CuO}$ composite showed the most reasonable high-temperature tribological behaviors. This was ascribed to the synergistic effects of silver, Mo, in situ formed solid lubricants (metal oxides and salt compounds), and the stable oxide film on the worn surfaces. At elevated temperatures, the dominant wear mechanism was oxidation wear.
\end{abstract}

Keywords: $\mathrm{FeCr}$ matrix composites; high temperature; friction; wear; $\mathrm{CuO}$

\section{Introduction}

High-temperature wear usually leads to the loss of mechanical strength and to a decrease in the service life of mechanical parts [1-3]. Nowadays, high-temperature mechanical parts are made of nickel and cobalt matrix materials due to their excellent oxidation resistance and mechanical strength. In some cases, ceramic matrix materials are also used under some rigorous working conditions. Although these materials have a considerable wear resistance at elevated temperatures, the cost is high. It is therefore necessary to develop composites with a low cost, a low friction coefficient, and a high wear resistance at elevated temperatures. Fe matrix material is one of the superalloys, which are widely used in many industrial fields as wear resistant mechanical parts [4,5]. High-temperature Fe matrix sleeves and bears always run at $600{ }^{\circ} \mathrm{C}$. However, wear resistance depends on the mechanical properties of materials at elevated temperatures [6,7], resulting in severe wear. Therefore, Fe matrix materials with a low cost and wear rate are promising materials for tribological application, providing strong motivation for engineers to improve the wear performance of Fe matrix materials to replace nickel and ceramic matrix materials at high temperatures.

The hardfacing of Fe alloys is a popular means to change the surface composition, so as to improve the wear properties, by using $C$ and $B$ elements $[8,9]$. The hard $\mathrm{Fe}(\mathrm{B}, \mathrm{C})$ phase can carry part of the normal load during the wear process in order to decrease the wear rate. However, brittleness is the 
inherent nature of the $\mathrm{Fe}(\mathrm{B}, \mathrm{C})$ phase, which easily fractures and peels off from the worn surface, destroying the wear resistance of alloys [10]. The surface modification methods do not change the bulk properties, which restricts their application as bulk materials. Kim et al. [11] reported the effect of Mn on the wear behaviors of Fe-20Cr matrix hardfacing alloys from 25 to $450{ }^{\circ} \mathrm{C}$. The results indicated that $\gamma \rightarrow \varepsilon$ martensitic transformation was beneficial to the wear resistance of alloys when Mn content exceeded $10 \mathrm{wt} . \%$. The excellent wear resistance of Fe matrix alloys could be achieved by adding hard ceramic particles, such as $\mathrm{SiC}, \mathrm{TiC}$, and $\mathrm{Al}_{2} \mathrm{O}_{3}$ [12-14]. Zhang et al. [15] prepared Fe-28Al-5Cr matrix composites reinforced by nano-TiC ceramic particles. High $\mathrm{TiC}$ content increased the wear resistance of the $\mathrm{Fe}-\mathrm{Al}-\mathrm{Cr}$ alloy at $800{ }^{\circ} \mathrm{C}$. However, TiC ceramic particles obviously destroyed the friction coefficient of composites-the friction coefficient was about 0.7. Solid lubricants work as an effective strengthening phase to reinforce the tribological properties of metal matrix composites at elevated temperatures [16-18]. During sliding, solid lubricants form a stable lubricating film on the contact surfaces in order to provide a lubricating effect for composites. Song et al. [19] investigated the wear and friction behaviors of a CuO/3Y-TZP composite. $\mathrm{CuO}$ reacted with $\mathrm{Al}_{2} \mathrm{O}_{3}$ and formed $\mathrm{CuAl}_{2} \mathrm{O}_{4}$ and $\mathrm{CuAlO}_{2}$. The $\mathrm{CuAlO}_{2}$ formed a soft surface layer which could reduce friction coefficients. $\mathrm{Ba}_{0.25} \mathrm{Sr}_{0.75} \mathrm{SO}_{4}$ showed a good lubricating effect in $\mathrm{Fe}_{3} \mathrm{Al}$ alloys [20,21]. $\mathrm{Ba}_{0.25} \mathrm{Sr}_{0.75} \mathrm{SO}_{4}$ softened and formed a lubricating film on the contact surfaces at elevated temperatures. However, the hardness and compactness of $\mathrm{Fe}_{3} \mathrm{Al}$ matrix composites degraded due to the addition of $\mathrm{Ba}_{0.25} \mathrm{Sr}_{0.75} \mathrm{SO}_{4}$ [20]. In our previous work [22], $\mathrm{BaF}_{2}$ was used to improve the wear resistance of $\mathrm{FeCr}$ matrix composites as high-temperature solid lubricants. The glaze film containing $\mathrm{BaF}_{2}$ and different compounds played an important part in the tribological properties. $\mathrm{FeCr}$ with $10 \% \mathrm{BaF}_{2}$ showed an excellent wear resistance from RT to $800{ }^{\circ} \mathrm{C}$. Nevertheless, the wear rates were in the order of $3.5 \times 10^{-4} \mathrm{~mm}^{3} / \mathrm{N}$.m. We thought that $\mathrm{FeCr}$ matrix self-lubricating composites could be further improved by adopting appropriate means.

In this research project, $\mathrm{FeCr}$ alloying powder was selected as a matrix. $\mathrm{Ag}$, Mo, and $\mathrm{CuO}$ were used to reinforce the tribological behaviors of $\mathrm{FeCr}$ matrix composites, and the $\mathrm{CuO}$ content was optimized. The powder metallurgy technique $(\mathrm{P} / \mathrm{M})$ was employed for preparing composites. Wear tests were carried out using a ball-on-disk high-temperature tribotester from room temperature $\left(24{ }^{\circ} \mathrm{C}\right)$ to $800^{\circ} \mathrm{C}$. The corresponding friction mechanisms were explored.

\section{Experimental Procedure}

\subsection{Specimens}

Fe (purity 99.5, $75 \mu \mathrm{m}$, Sinopharm Chemical Reagent Co., Ltd., Shanghai, China) and Cr (purity 99.3, $60 \mu \mathrm{m}$, Sinopharm Chemical Reagent Co., Ltd., Shanghai, China) powders were used as the raw materials to prepare $\mathrm{Fe}-21 \mathrm{wt} . \% \mathrm{Cr}$ alloying powder. Firstly, $\mathrm{Fe}$ and $\mathrm{Cr}$ powders were mixed in a planetary ball mill and then sintered at $1100{ }^{\circ} \mathrm{C}$ in a furnace. The alloying powder was milled by a high-energy mill for $12 \mathrm{~h}$, and the rotational speed was $300 \mathrm{rpm}$ [22]. The mean size of the Fe-21 wt.\% Cr alloying powder was about $40 \mu \mathrm{m}$. The sizes of the $\mathrm{Ag}$, Mo, and $\mathrm{CuO}$ powders (Sinopharm Chemical Reagent Co., Ltd., Shanghai, China) used were about 65, 25, and $75 \mu \mathrm{m}$, respectively. The different powders were weighted according to Table 1 . The composites were denoted as FC, FU, FM, FAC10, FAC6, and FAC14. The raw materials were mechanically mixed together by a high-energy mill for $8 \mathrm{~h}$, and the rotational speed was $150 \mathrm{rpm}$. The ratio of powder to ball was 8:1. Mixtures were put into a graphite die (inner diameter: $30 \mathrm{~mm}$ ). Composites were sintered under a pressure of $35 \mathrm{MPa}$ for $30 \mathrm{~min}$ at $1150^{\circ} \mathrm{C}$ in a vacuum hot-pressing furnace. 
Table 1. Composition of composites (mass\%).

\begin{tabular}{ccccc}
\hline Specimens & Fe-21Cr & Mo & Ag & CuO \\
\hline FC & 100 & 0 & 0 & 0 \\
FU & 90 & 0 & 0 & 10 \\
FM & 76 & 14 & 0 & 10 \\
FAC10 & 65.5 & 14 & 10.5 & 10 \\
FAC6 & 69.5 & 14 & 10.5 & 6 \\
FAC14 & 61.5 & 14 & 10.5 & 14 \\
\hline
\end{tabular}

\subsection{Tribological Tests}

The wear and friction performances were evaluated on a tribometer (Zhongke Kaihua Co., Ltd., Lanzhou, China) with a ball-on-disk configuration from 24 to $800{ }^{\circ} \mathrm{C}$ in air. The counterpart was a $\mathrm{Si}_{3} \mathrm{~N}_{4}$ ceramic ball with a diameter of $6 \mathrm{~mm}$, and its hardness was about $15 \mathrm{GPa}(\mathrm{Hv})$. The ceramic ball was fixed. FeCr matrix composites were cut into disks with a size of $\varnothing 30 \mathrm{~mm} \times 4 \mathrm{~mm}$. Before the tests, the testing surfaces were polished to an average roughness of $0.34 \mu \mathrm{m}\left(\mathrm{R}_{\mathrm{a}}\right)$ and the disks were rotated. The testing speed and normal load were $0.19 \mathrm{~m} / \mathrm{s}$ and $10 \mathrm{~N}$, respectively. The duration of the test was $20 \mathrm{~min}$, and the turning radius was $5 \mathrm{~mm}$. The testing temperatures were room temperature $\left(24^{\circ} \mathrm{C}\right)$, $200,400,600$, and $800^{\circ} \mathrm{C}$. Each experimental point was repeated three times in order to ensure the accuracy of the data. The friction coefficients of the composites were recorded online by a computer.

The microstructures and worn surfaces of the composites were analyzed using scanning electron microscopy (SEM, IT-300, JEOL, Tokyo, Japan) and energy dispersive spectroscopy (EDS, Inca X-MAX-100, Oxford, England). The phases of the composites were characterized by X-ray diffraction (XRD, DIFFRACTOMETER-6000, 40 kV, 30 mA, Cu Ka radiation, Tokyo, Japan). Archimedes' method was explored to determine the density of the testing specimens. The hardness was measured using a Vickers indentation (MH-5 micro-hardness tester, Suzhou, China). The test load was $200 \mathrm{~g}$, and the $\mathrm{d}$ well time was $10 \mathrm{~s}$. The hardness reported here was the average value of ten measurements. The wear depth profiles of the wear tracks were examined by a contact surface profiler to calculate the wear volume of composites. The specific wear rate was calculated as the wear volume $\left(\mathrm{mm}^{3}\right)$ divided by the sliding distance $(\mathrm{m})$ and the applied load $(\mathrm{N})$, and its unit was $\mathrm{mm}^{3} / \mathrm{N} . \mathrm{m}$.

\section{Results and Discussion}

\subsection{Microstructure and Physical Properties of Composites}

The XRD patterns of the obtained FeCr matrix composites are given in Figure 1. The Fe element reacts with $\mathrm{Cr}$ and forms a $\mathrm{FeCr}$ phase due to the high-temperature solid solution reaction at an elevated temperature [23]. With the addition of Mo, some new diffraction peaks were detected from the specimens, such as the $\mathrm{CrMoO}_{3}, \mathrm{FeMoO}_{4}$, and $\mathrm{Mo}_{5} \mathrm{Cr}_{6} \mathrm{Fe}_{18}$ phases. This is ascribed to the complex high-temperature reaction between $\mathrm{Mo}$ and other elements during solidification. These phases are expected to improve the mechanical and tribological properties of composites. Therefore, the following chemical reactions are reasonable:

$$
\begin{gathered}
\mathrm{Fe}+\mathrm{Cr} \rightarrow \mathrm{FeCr} \\
7 \mathrm{Mo}+19 \mathrm{Fe}+7 \mathrm{Cr}+7 / 2 \mathrm{O}_{2} \rightarrow \mathrm{CrMoO}_{3}+\mathrm{FeMoO}_{4}+\mathrm{Mo}_{5} \mathrm{Cr}_{6} \mathrm{Fe}_{18}
\end{gathered}
$$

According to the XRD pattern, the peaks of $\mathrm{CuO}$ are obvious, indicating that the $\mathrm{CuO}$ showed a high stability in the composites. Silver was present in its simple substance phase in the matrix. For FAC6, FAC10, and FAC14, the main phases consisted of Fe, $\mathrm{FeCr}, \mathrm{CrMoO}_{3}, \mathrm{FeMoO}_{4}, \mathrm{Mo}_{5} \mathrm{Cr}_{6} \mathrm{Fe}_{18}$, $\mathrm{CuO}$, and $\mathrm{Ag}$. 


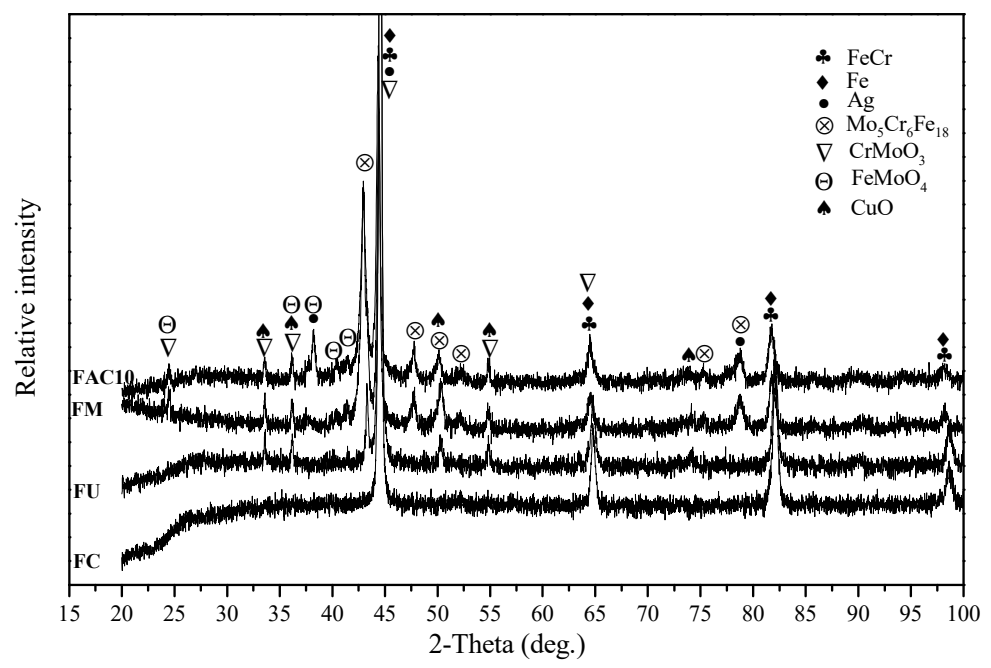

Figure 1. XRD patterns of obtained composites.

Figure 2 illustrates the typical microstructures and element distribution maps of FC, FU, FM, and FAC10. The figure shows that the composites had a dense microstructure, which is of benefit to the mechanical properties of the composites. The composites showed different microstructures because of differences in their composition. $\mathrm{CuO}$ was mainly distributed at the interface of $\mathrm{FeCr}$ metal particles (see Figure $2 b$ ), and $\mathrm{CuO}$ formed a network structure in the matrix. Mo can be seen as a bridge of metal particles when it is distributed along the interface. During solidification, Mo can react with FeCr metal particles and form intermetallic compounds induced by atom diffusion at the interface, which leads to the formation of a sintering neck of metal particles in the matrix. In addition, with the formation of a sintering neck, part of the $\mathrm{CuO}$ phrase was squeezed out from the interface of metal particles and showed an aggregation phenomenon (see Figure 2c). Due to this, the continuity of the matrix was improved. With increasing temperature, silver filled the gaps in the matrix because of its excellent toughness. The $\mathrm{CuO}$ was further squeezed out of the interfaces. Meanwhile, the chemical reaction accelerated, which reinforced the sintering neck of the metal particles and improved the continuity of the matrix in comparison with those of FU and FM. Additionally, the aggregation phenomenon of $\mathrm{CuO}$ became more and more obvious (see Figure 2d). Taking EDS element distribution maps and $\mathrm{XRD}$ patterns into account, the gray area is the mixed phases of $\mathrm{Fe}$ and $\mathrm{FeCr}$. The Mo-rich phase is the light-gray area that contains complex compounds (see Figures 1 and $2 \mathrm{~g}$ ). Silver and $\mathrm{CuO}$ were dispersed in the matrix (see Figure 2i,j).

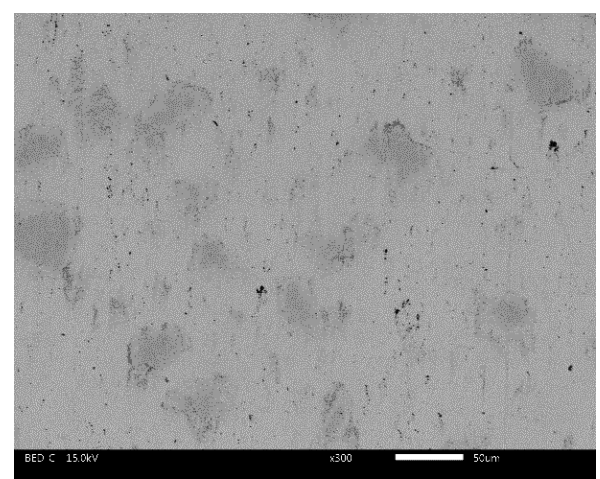

(a)

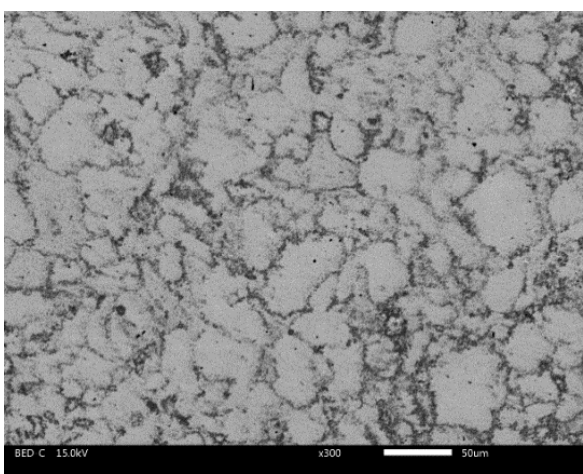

(b)

Figure 2. Cont. 


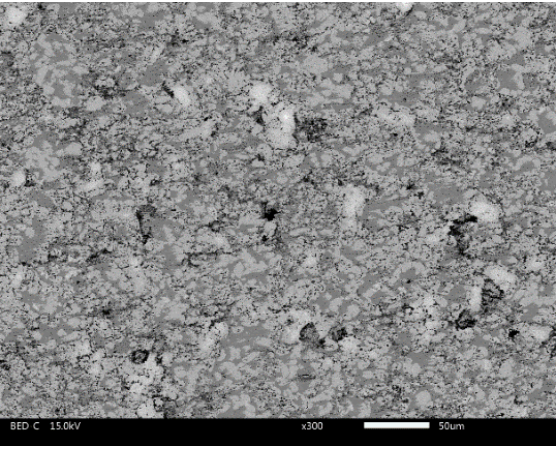

(c)

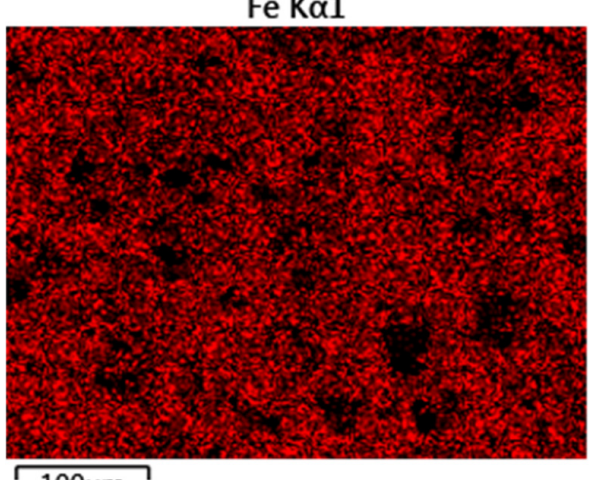

(e)

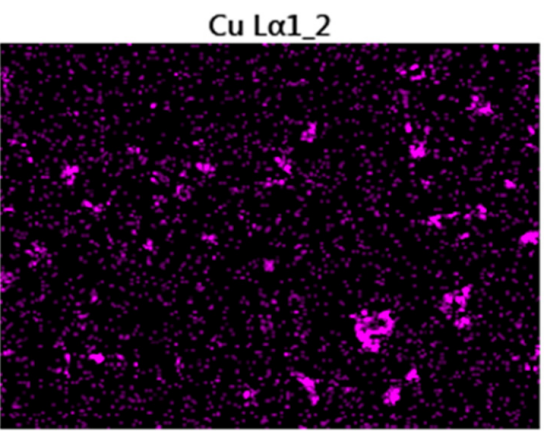

$\longdiv { 1 0 0 \mu \mathrm { m } }$

(g)

Mo L $\alpha 1$

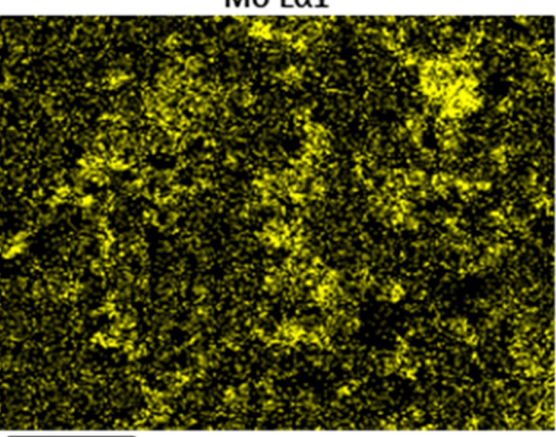

$100 \mu \mathrm{m}$

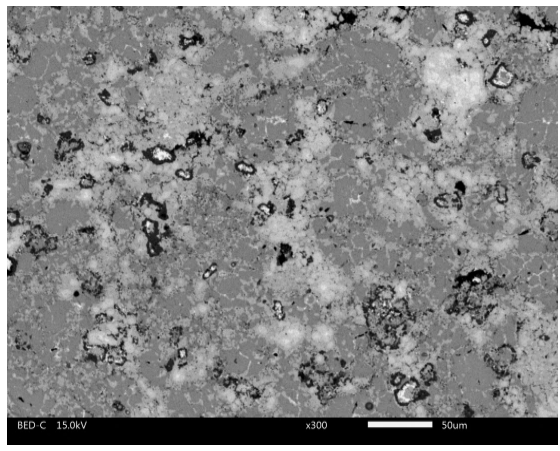

(d)

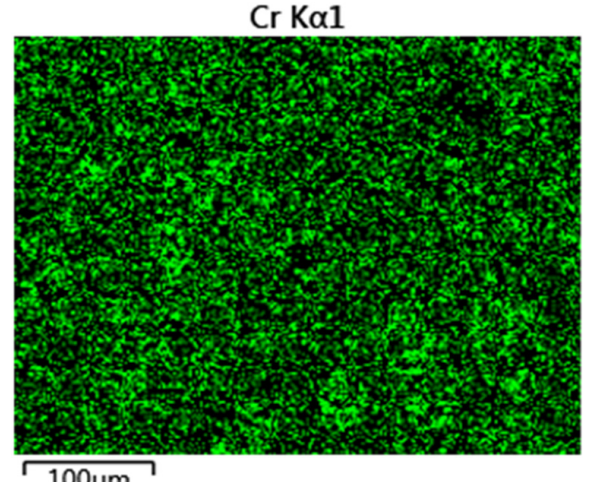

(f)

$\mathrm{O} K \alpha 1$

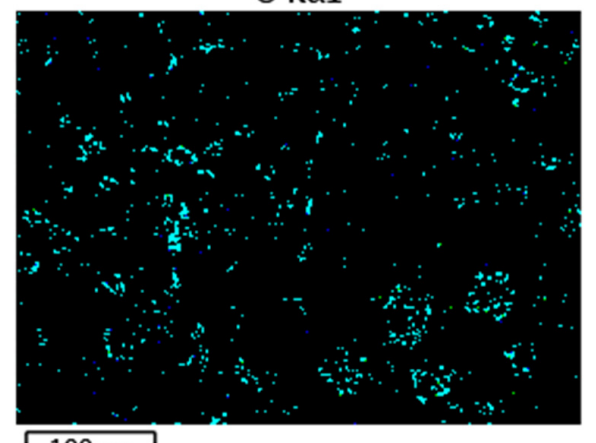

(h)

Ag $L \alpha 1$

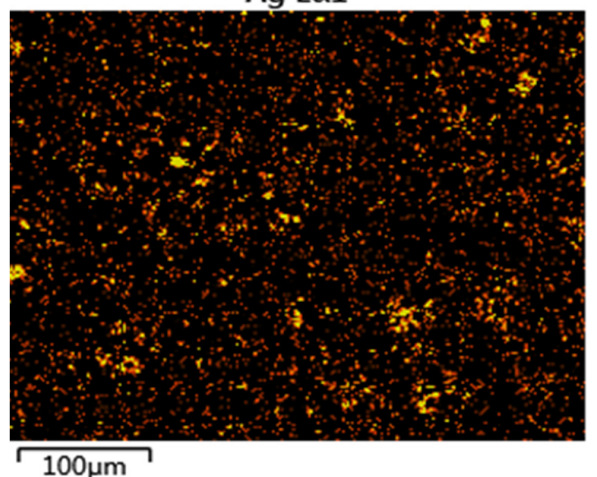

(j)

Figure 2. Microstructures of obtained composites: (a) FC, (b) FU, (c) FM and (d) FAC10; EDS element distribution maps of FAC10: (e) Fe, (f) $\mathrm{Cr},(\mathbf{g}) \mathrm{Mo},(\mathbf{h}) \mathrm{O}$, (i) $\mathrm{Ag}$ and (j) Cu. 
Table 2 gives the hardness, density, and porosity of specimens. Although the $\mathrm{CuO}$ phase destroys the continuity of the matrix, $\mathrm{CuO}$ can restrict the slip of dislocation and the propagation of a crack as the second phase when the deformation occurs. In this case, $\mathrm{CuO}$ possessed an obvious particle strengthening effect on the matrix. Therefore, the hardness of composites increases with increasing $\mathrm{CuO}$ content. Mo formed intermetallic compounds and salt compounds in the matrix. This indicates that Mo has a solid solution strengthening effect on composites. Meanwhile, the addition of Mo improves the formation of the sintering neck of FeCr metal particles. Based on these two factors, the hardness and compactness of composites further increase. The silver, with a low hardness, was dispersed in the matrix and influenced the continuity of the matrix to some degree. Silver leads to a decrease in the hardness of composites. Nevertheless, the hardness of the specimens with silver were higher than that of other specimens. The hardness of the composites was about 1.3 times higher than that of composites without solid lubricants. Concerning density, it is easy to explain why the sintered density of the composites decreased with the increase of low density $\mathrm{CuO}$-due to the wettability of the $\mathrm{CuO}$ phase and metal matrix, small voids could accumulate at the interfaces. As a result, the porosity increased slightly with increasing $\mathrm{CuO}$ content.

Table 2. Vickers hardness, density, and porosity of obtained composites.

\begin{tabular}{cccc}
\hline Specimens & Vickers Hardness & Density $\mathbf{( g / \mathbf { c m } ^ { 3 } )}$ & Porosity (\%) \\
\hline FC & 176 & 7.69 & 0.43 \\
FU & 192 & 7.44 & 1.91 \\
FM & 445 & 7.68 & 1.76 \\
FAC10 & 403 & 7.94 & 1.37 \\
FAC6 & 386 & 8.04 & 0.86 \\
FAC14 & 428 & 7.83 & 1.94 \\
\hline
\end{tabular}

\subsection{High-Temperature Tribological Properties}

The friction coefficients of specimens at different temperatures sliding against a $\mathrm{Si}_{3} \mathrm{~N}_{4}$ ball are shown in Figure 3. The friction coefficients of composites generally decreased as temperature increased. At 600 and $800^{\circ} \mathrm{C}, \mathrm{FU}$ had a lower friction coefficient than that of FC. The friction coefficients of FM were lower than those of specimens FC and FU from 400 to $800{ }^{\circ} \mathrm{C}$. Due to the addition of silver, the friction coefficients of composites decreased at low temperatures. FA6, FA10, and FA14 with CuO and silver kept low friction coefficients from RT to $800^{\circ} \mathrm{C}$, and the friction coefficients increased with increasing $\mathrm{CuO}$ content below $600{ }^{\circ} \mathrm{C}$. At $800{ }^{\circ} \mathrm{C}$, the friction coefficients show the opposite trend.

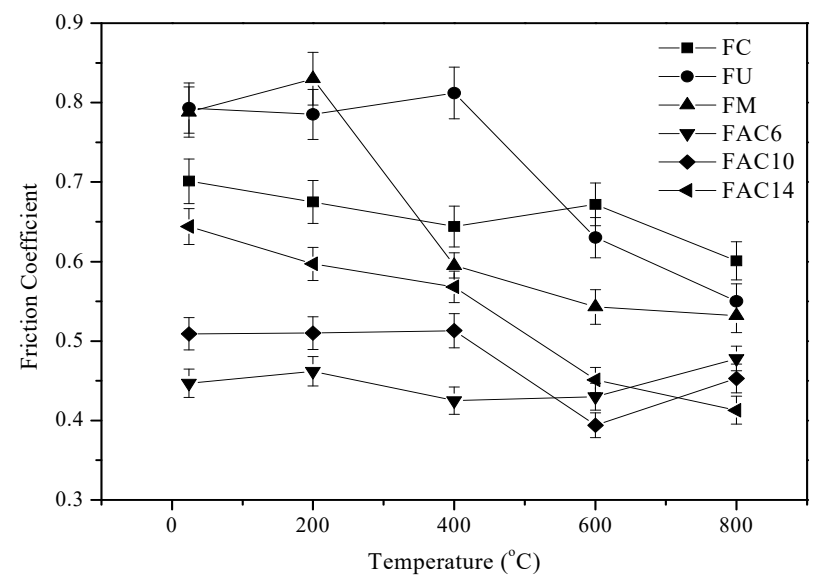

Figure 3. Variations of friction coefficients of the obtained composites with temperature at $10 \mathrm{~N}$ and $0.19 \mathrm{~m} / \mathrm{s}$. 
Figure 4 illustrates the vibrations of the wear rates of specimens at different temperatures sliding against a $\mathrm{Si}_{3} \mathrm{~N}_{4}$ ball. The wear rates of different composites show different trends from 24 to $800{ }^{\circ} \mathrm{C}$. $\mathrm{FC}$ had the highest wear rates. Especially, at $800^{\circ} \mathrm{C}$, the wear rate was about $3.4 \times 10^{-2} \mathrm{~mm}^{3} / \mathrm{N} . \mathrm{m}$. This means that $800{ }^{\circ} \mathrm{C}$ exceeds the working temperature of the FeCr material. It is clear that the wear rates of composites decrease due to the addition of $\mathrm{Mo}, \mathrm{CuO}$, and $\mathrm{Ag}$. The wear rates of FM, FAC6, and FAC10 were in the order of $10^{-5} \mathrm{~mm}^{3} / \mathrm{N} . \mathrm{m}$ and that of FAC14 was in the order of $10^{-6} \mathrm{~mm}^{3} / \mathrm{N} . \mathrm{m}$. FAC14 had the lowest wear rates from 24 to $800{ }^{\circ} \mathrm{C}$. The working temperature of modified FeCr matrix composites can reach up to $800{ }^{\circ} \mathrm{C}$. The wear rates of composites containing $\mathrm{CuO}$ were about 15-100 times lower than that of the specimen with $\mathrm{CaF}_{2}$ from room temperature to $800^{\circ} \mathrm{C}$ [22]. The wear mechanism is discussed below.
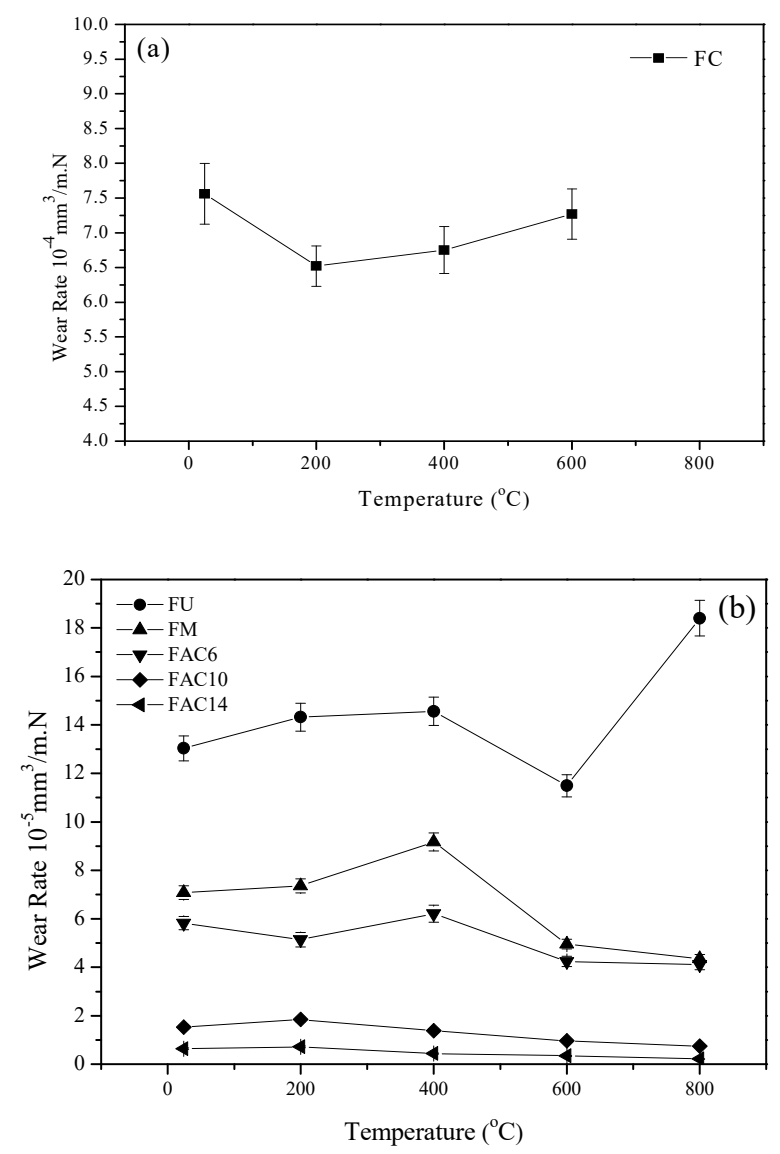

Figure 4. Variations of the wear rates of the obtained composites with temperature at $10 \mathrm{~N}$ and $0.19 \mathrm{~m} / \mathrm{s}$ : (a) FC and (b) FU, FM, FAC6, FAC10, and FAC14.

Temperature is an important factor for the high-temperature friction and wear behaviors of materials [24-26]. At elevated temperatures, metal elements and wear debris are easily oxidized in order to produce a large amount of oxides on the wear tracks (see Figure 5). These oxides and compounds were ground by the tribo-couples and formed an obvious oxide film on the wear tracks. During sliding, the oxide film reduces the real contact area of tribo-couples and can provide a lubricating effect for the composites at elevated temperatures. When the testing temperature was low, the oxide content was low and there was no obvious oxide film on the wear tracks (see Figure 6). Thus, the friction coefficients and wear rates of composites decrease when the temperature increases. $\mathrm{CuO}$ does not have a lubricating effect at low temperatures. At low temperatures, $\mathrm{CuO}$ increases the sliding resistance in order to increase the friction coefficients of the composites as a third body. This trend becomes more and more obvious with increasing $\mathrm{CuO}$ content. However, at high temperatures, $\mathrm{CuO}$ shows a lubricating effect on composites as a high-temperature solid lubricant. Erdemir et al. [27] established an ionic potential $(\Phi=Z / r)$ lubricating effect model of metal oxides at elevated temperatures. They found 
that metal oxides with a high ionic potential have good shear performance, i.e., the oxides have a good lubricating effect. Additionally, they also investigated dual systems of metal oxides as solid lubricants and found that the greater the difference of the ionic potential of two metal oxides, the better the lubricating effect. In this study, the ionic potential of $\mathrm{MoO}_{3}$ was 8.95. Therefore, $\mathrm{MoO}_{3}$ can show a lubricating effect to some extent. The differences of $\mathrm{MoO}_{3}-\mathrm{CuO}$ (2.73), $\mathrm{MoO}_{3}-\mathrm{Cr}_{2} \mathrm{O}_{3}(4.84)$, $\mathrm{MoO}_{3}-\mathrm{Fe}_{2} \mathrm{O}_{3}$ (5.45), and $\mathrm{MoO}_{3}-\mathrm{Ag}_{2} \mathrm{O}(0.79)$ were 6.22, 4.11, 3.5, and 8.16, respectively. $\mathrm{MoO}_{3}-\mathrm{CuO}$, $\mathrm{MoO}_{3}-\mathrm{Cr}_{2} \mathrm{O}_{3}, \mathrm{MoO}_{3}-\mathrm{Fe}_{2} \mathrm{O}_{3}$, and $\mathrm{MoO}_{3}-\mathrm{Ag}_{2} \mathrm{O}$ systems can show excellent lubricating effects due to the formation of $\mathrm{CuMoO}_{4}, \mathrm{FeMoO}_{4}, \mathrm{Cu}_{3} \mathrm{Mo}_{2} \mathrm{O}_{9}$, and $\mathrm{Ag}_{2} \mathrm{MoO}_{4}$ during sliding [27,28]. The Mo element is not a solid lubricant as an alloying element. However, Mo shows a lubricating effect when Mo produces $\mathrm{CrMoO}_{3}, \mathrm{FeMoO}_{4}$, and $\mathrm{MoO}_{3}[22,28]$. Therefore, the specimens with Mo kept low friction coefficients and wear rates at elevated temperatures. Silver is an effective low-temperature solid lubricant because of its excellent ductility [29]. At high temperatures, Ag provides lubrication when it changes into $\mathrm{Ag}_{2} \mathrm{MoO}_{4}$ [27]. Due to the effect of $\mathrm{Ag}$ and $\mathrm{Ag}_{2} \mathrm{MoO}_{4}$, the wear and friction of the composites with silver further decreased from RT to $800{ }^{\circ} \mathrm{C}$. The mechanical properties of materials also determine the wear rates of materials. The hardness of materials is the most important factor [30]. Materials with a high hardness have low wear rates. With the addition of $\mathrm{CuO}$ and $\mathrm{Mo}$, the hardness of composites increases in order for the wear rates of composites to decrease. Although the specimens containing silver and $\mathrm{CuO}$ had a low hardness in comparison with that of FM, the in-situ formed solid lubricants, oxide film, and adding solid lubricants compensated for the influence of hardness. Therefore, FAC6, FAC10, and FAC14 kept low friction coefficients and wear rates from room temperature to $800{ }^{\circ} \mathrm{C}$. FAC14 had the lowest wear rates but had a high friction coefficient. The obtained results indicate that $10 \mathrm{wt} . \% \mathrm{CuO}$ is a critical threshold at which there is a transition of friction coefficients and wear rates. In general, FAC10 had the most reasonable tribological properties from room temperature to $800{ }^{\circ} \mathrm{C}$. Therefore, the operating temperature of reinforced materials could reach $800{ }^{\circ} \mathrm{C}$.

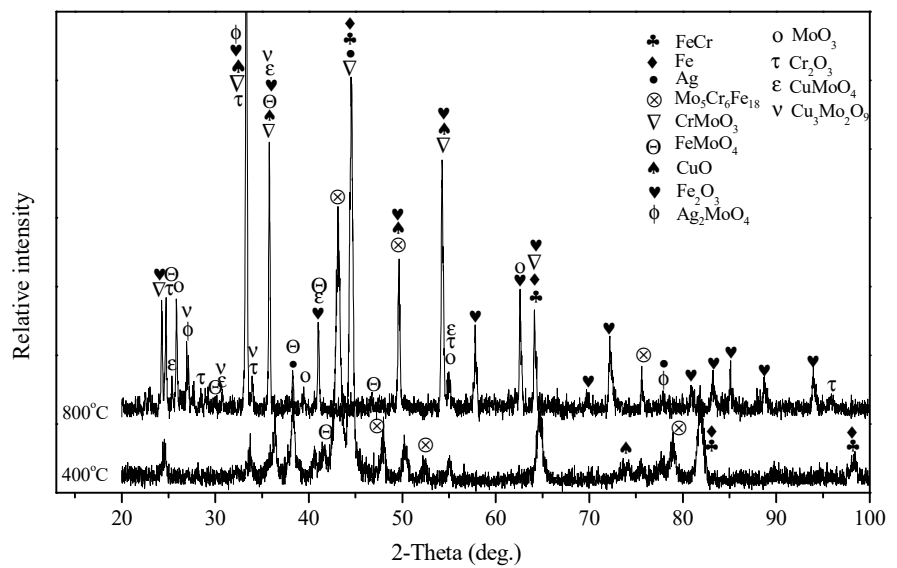

Figure 5. XRD patterns of the worn surfaces of FAC10 at 400 and $800{ }^{\circ} \mathrm{C}$.

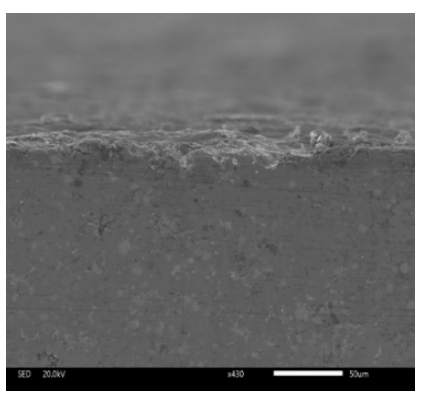

(a)

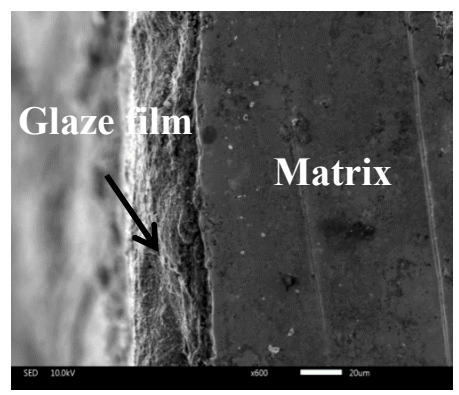

(b)

Figure 6. SEM images of cross sections for FAC10 at (a) $400{ }^{\circ} \mathrm{C}$ and (b) $800{ }^{\circ} \mathrm{C}$. 


\subsection{Analysis of Worn Surfaces}

Figure 7 gives the worn morphologies of FC, FU, FM, and FAC10 at RT sliding against a $\mathrm{Si}_{3} \mathrm{~N}_{4}$ ball. The worn surfaces of FC, FU, and FM were characterized by flaking pits and a smooth area at room temperature (see Figure 7a-c). During sliding, the hardness of the Fe phase in the matrix decreases due to the friction heat [23]. Firstly, the Fe phase deforms plastically. The alloying phases $(\mathrm{Fe}(\mathrm{Cr}, \mathrm{Mo}))$ with high hardness could support external loads and restrict the extension of plastic deformation, resulting in the size of the flaking pits decreasing with the addition of $\mathrm{CuO}$ and Mo. This indicates that the wear mechanisms of FC, FU, and FM were plastic deformation and fatigue wear at RT. FAC10 showed a distinct morphology compared with those of other specimens (see Figure 7d). The wear track presented slight grooves, deformation, and flaking pits. Silver with high toughness can be smeared on the wear tracks (see Table 3) to provide a lubricating effect in order to reduce the friction heat [27]. The dominant wear mechanism of FAC10 was plowing with slight fatigue wear at room temperature. At $400{ }^{\circ} \mathrm{C}, \mathrm{FC}$ and FU showed characteristics of severe plastic deformation and flaking pits (see Figure $8 \mathrm{a}, \mathrm{b}$ ). This also corresponds to the high wear rates of composites at $400^{\circ} \mathrm{C}$. The worn surfaces of FM and FAC10 were smoother than those of FC and FU (see Figure 8c,d). The in situ formed lubricants started to provide a lubricating effect for the composites at $400{ }^{\circ} \mathrm{C}$. The wear mechanisms of FM and FAC10 were characterized by plowing and slight plastic deformation. FC suffered from severe wear at $80{ }^{\circ} \mathrm{C}$, the worn surface was completely destroyed (see Figure 9a), and a crack and delamination were noted on the worn surface. This means that FC had a high wear rate at $800^{\circ} \mathrm{C}$. In other cases, the solid lubricants, oxides, and compounds form an obvious lubricating film on the worn surfaces $[24,31]$ (see Figure 9b-d). Additionally, the substrate with high hardness can support the formation of lubricating film on the contact surfaces. This film can protect the surfaces and restrict the process of oxidation-oxide-removal-oxidation. Meanwhile, the lubricating film also reduces the contact area of tribo-couples, so as to improve the tribological performance of composites at elevated temperatures [31]. The main wear mechanism of the obtained composites was oxidation wear with slight plowing at $800^{\circ} \mathrm{C}$.

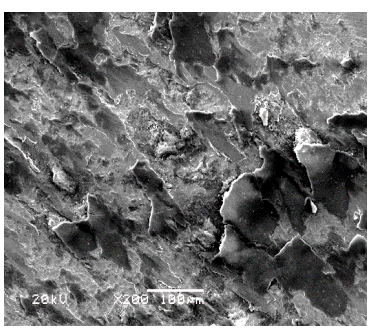

(a)

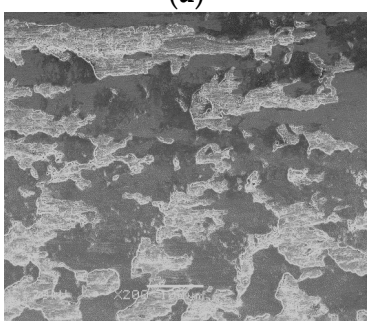

(c)

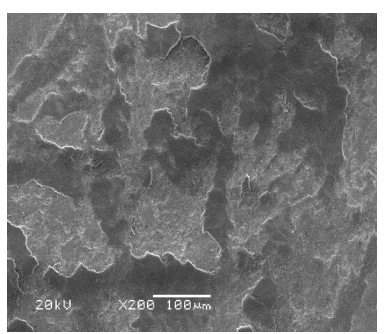

(b)

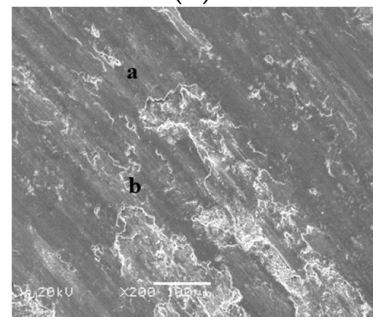

(d)

Figure 7. SEM images of the wear morphologies of different composites at room temperature: (a) FC, (b) FU, (c) FM, and (d) FAC10.

Table 3. Composition of Areas a and b in Figure 7d.

\begin{tabular}{ccccccccc}
\hline \multirow{2}{*}{ Area } & \multicolumn{7}{c}{ Element (wt.\%) } \\
\cline { 2 - 9 } & $\mathbf{N}$ & $\mathbf{O}$ & $\mathbf{S i}$ & $\mathbf{C r}$ & $\mathbf{F e}$ & $\mathbf{C u}$ & $\mathbf{M o}$ & $\mathbf{A g}$ \\
\hline $\mathrm{a}$ & 0.31 & 24.35 & 0.78 & 9.17 & 21.11 & 13.35 & 9.42 & 21.51 \\
\hline $\mathrm{b}$ & 0.28 & 25.31 & 0.64 & 9.84 & 22.63 & 10.51 & 10.42 & 20.37 \\
\hline
\end{tabular}




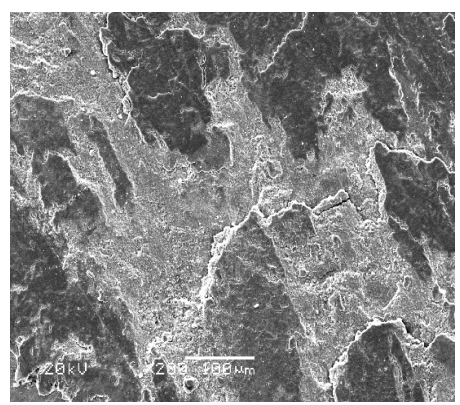

(a)

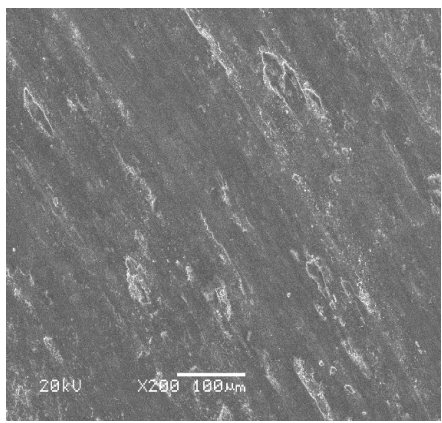

(c)

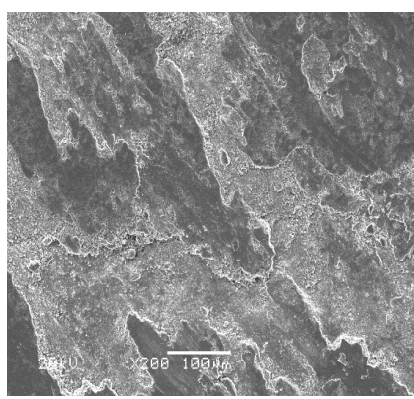

(b)

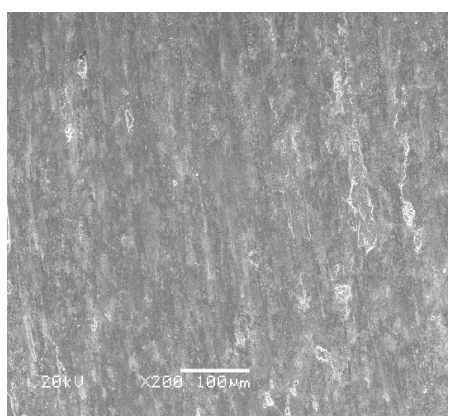

(d)

Figure 8. SEM images of the wear morphologies of different composites at $400{ }^{\circ} \mathrm{C}:(\mathbf{a}) \mathrm{FC},(\mathbf{b}) \mathrm{FU}$, (c) FM, and (d) FAC10.

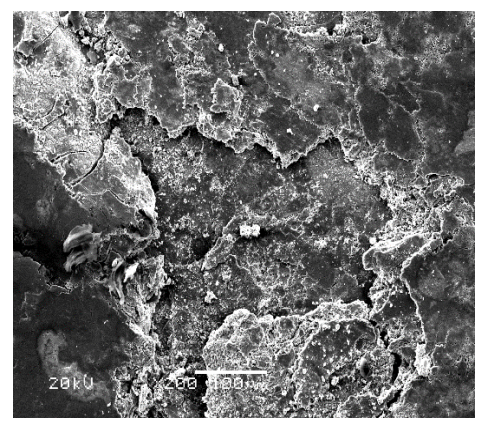

(a)

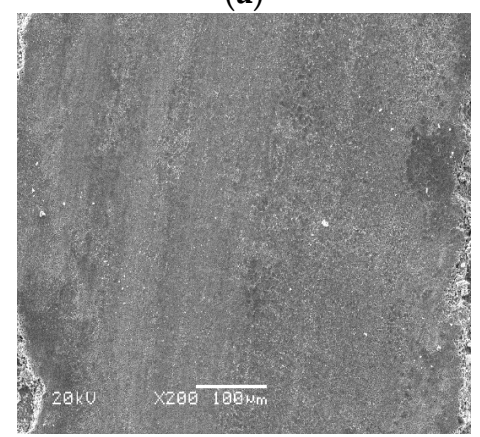

(c)

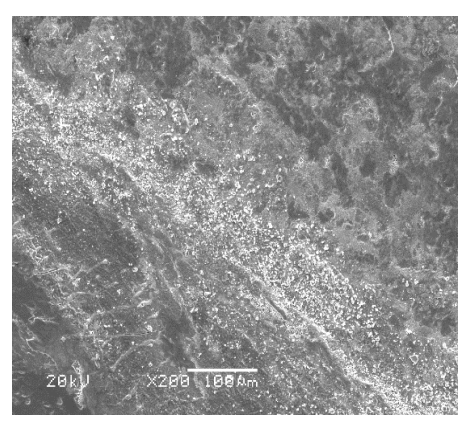

(b)

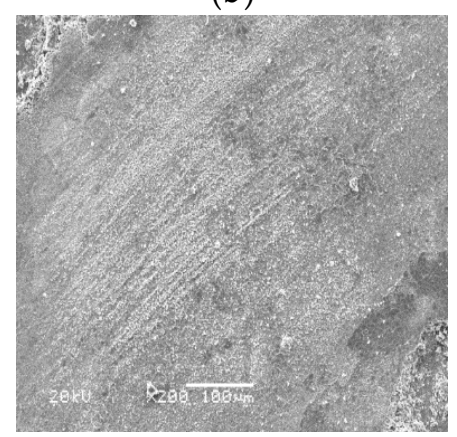

(d)

Figure 9. SEM images of the wear morphologies of different composites at $800{ }^{\circ} \mathrm{C}:(\mathbf{a}) \mathrm{FC},(\mathbf{b}) \mathrm{FU}$, (c) FM, and (d) FAC10.

The worn surfaces of the $\mathrm{Si}_{3} \mathrm{~N}_{4}$ balls sliding against FAC10 at different temperatures are shown in Figure 10. It is clear from the figure that a transferred layer was found on the wear scars of balls from 24 to $800{ }^{\circ} \mathrm{C}$, and the transferred layer increased with increasing testing temperatures. 
The transferred layer can protect the tribo-couples during friction. The presence of a transferred layer can change the contact model between the composites and the ceramic balls to reduce wear and friction at high temperatures.

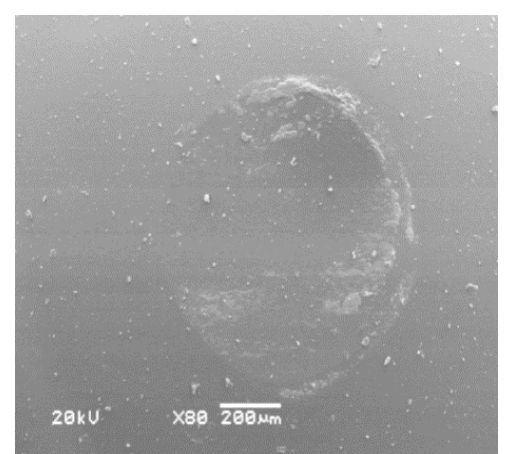

(a)

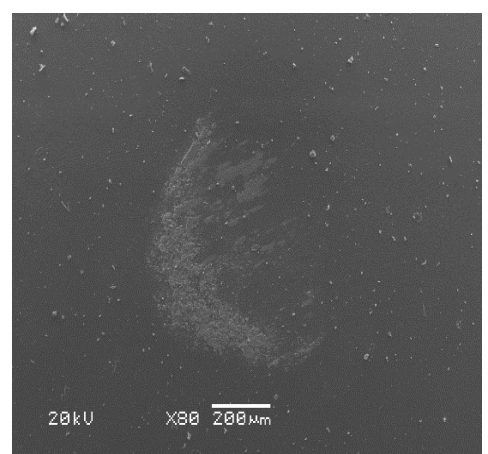

(b)

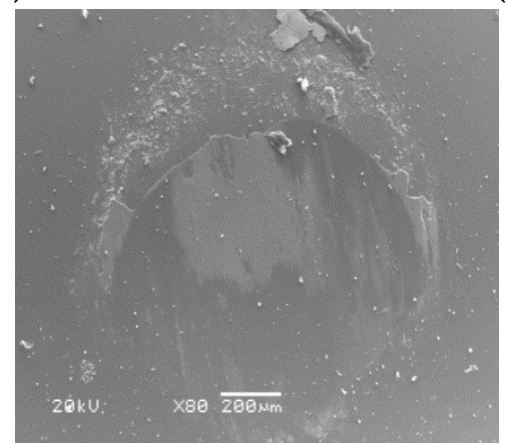

(c)

Figure 10. Wear morphologies of Si3N4 balls sliding against FAC10 at different temperatures: (a) $24{ }^{\circ} \mathrm{C}$, (b) $400{ }^{\circ} \mathrm{C}$, and (c) $800^{\circ} \mathrm{C}$.

\section{Conclusions}

(1) The addition of $\mathrm{Mo}, \mathrm{Ag}$, and $\mathrm{CuO}$ greatly changed the microstructure, phases, and hardness. The continuity of the matrix was improved. The distribution of $\mathrm{CuO}$ transferred from a network to an agglomeration state in the matrix. The Mo element showed a solid solution strengthening effect and a lubricating effect when it changed into $\mathrm{CrMoO}_{3}, \mathrm{FeMoO}_{4}, \mathrm{CuMoO}_{4}, \mathrm{Cu}_{3} \mathrm{Mo}_{2} \mathrm{O}_{9}, \mathrm{Ag}_{2} \mathrm{MoO}_{4}$, and $\mathrm{MoO}_{3} . \mathrm{CuO}$ had a particle strengthening effect on the matrix. The hardness of the composites was about 1.3 times higher than that of composites without solid lubricants;

(2) Composition significantly influenced the tribological properties of composites. The friction coefficients increased with increasing $\mathrm{CuO}$ content. At $800^{\circ} \mathrm{C}$, the composite with a high $\mathrm{CuO}$ content had the lowest friction coefficient. The wear rates decreased with the increase of $\mathrm{CuO}$. This was ascribed to the in situ formed lubricants $\left(\mathrm{CrMoO}_{3}, \mathrm{FeMoO}_{4}, \mathrm{CuMoO}_{4}, \mathrm{Cu}_{3} \mathrm{Mo}_{2} \mathrm{O}_{9}, \mathrm{Ag}_{2} \mathrm{MoO}_{4}\right.$, and $\left.\mathrm{MoO}_{3}\right)$, silver, $\mathrm{CuO}$, and the stable oxide film. Additionally, the hardness of composites also played an important part in the wear resistance. The critical threshold at which there was a transition of tribological behaviors was $10 \mathrm{wt} . \% \mathrm{CuO}$. $\mathrm{Fe}(\mathrm{Cr})-14 \% \mathrm{Mo}-10.5 \% \mathrm{Ag}-10 \% \mathrm{CuO}$ showed the most reasonable tribological properties from 24 to $800{ }^{\circ} \mathrm{C}$. The wear rates were about 35 times lower than those of FeCr material. The prepared $\mathrm{FeCr}$ matrix self-lubricating composites could replace nickel and ceramic matrix composites;

(3) $\mathrm{MoO}_{3}-\mathrm{CuO}, \mathrm{MoO}_{3}-\mathrm{Cr}_{2} \mathrm{O}_{3}, \mathrm{MoO}_{3}-\mathrm{Fe}_{2} \mathrm{O}_{3}$, and $\mathrm{MoO}_{3}-\mathrm{Ag}_{2} \mathrm{O}$ systems can show excellent lubricating effects due to the formation of $\mathrm{CuMoO}_{4}, \mathrm{FeMoO}_{4}, \mathrm{Cu}_{3} \mathrm{Mo}_{2} \mathrm{O}_{9}$, and $\mathrm{Ag}_{2} \mathrm{MoO}_{4}$ during sliding. Bimetallic oxides with a high ionic potential difference formed high-temperature solid lubricants;

(4) The wear mechanisms of the composites were plastic deformation and fatigue wear at low temperatures. At elevated temperatures, the dominant wear mechanism was oxidation wear. 
Author Contributions: Funding acquisition, G.C.; methodology, Y.L. and G.C.; investigation, G.G., H.L., and Z.K.; writing - original draft, G.C. and Y.L. All authors have read and agreed to the published version of the manuscript.

Funding: This research was funded by the National Natural Science Foundation of China, grant numbers 51775365 and 51405329, and the Chinese Scholarship Fund, grant number 201906935012.

Conflicts of Interest: The authors declare no conflict of interest.

\section{References}

1. Varga, M.; Leroch, S.; Rojacz, H.; Ripoll, M.R. Study of wear mechanisms at high temperature scratch testing. Wear 2017, 388, 112-118. [CrossRef]

2. Zhong, Y.; Zhou, C.; Chen, S.; Wang, R.Y. Effects of temperature and pressure on stress corrosion cracking behavior of 310S stainless steel in chloride solution. Chin. J. Mech. Eng. 2016, 30, 200-206. [CrossRef]

3. Hou, G.L.; An, Y.L.; Zhao, X.Q.; Zhou, H.D.; Chen, J.M. Effect of alumina dispersion on oxidation behavior as well as friction and wear behavior of HVOF-sprayed CoCrAlYTaCSi coating at elevated temperature up to $1000^{\circ} \mathrm{C}$. Acta Mater. 2015, 95, 164-175. [CrossRef]

4. Gonzalez, J.; Peral, L.B.; Zafra, A.; Fernandez-Pariente, I. Influence of shot peening treatment in erosion wear behavior of high chromium white cast iron. Metals 2019, 9, 933. [CrossRef]

5. Qiu, B.; Xing, S.M.; Dong, Q. Green preparation and dry sliding wear properties of a Macro-ZTA/Fe composite produced by a two-step method. Metals 2019, 9, 986. [CrossRef]

6. Erdoğan, A. Investigation of high temperature dry sliding behavior of borided H13 hot work tool steel with nanoboron powder. Surf. Coat. Technol. 2019, 357, 886-895. [CrossRef]

7. Hernandez, S.; Hardell, J.; Courbon, C.; Winkelmann, H.; Prakash, B. High temperature friction and wear mechani sm map for tool steel and boron steel tribopair. Tribol.-Mater. Surf. Interfaces 2014, 8, 74-78. [CrossRef]

8. Yoo, J.W.; Lee, S.H.; Yoon, C.S.; Kim, S.J. The effect of boron on the wear behavior of iron-based hardfacing alloys for nuclear power plants valves. J. Nucl. Mater. 2006, 352, 90-96. [CrossRef]

9. Katsicha, C.; Badisch, E.; Roy, M.; Heath, G.R.; Franek, F. Erosive wear of hardfaced Fe-Cr-C alloys at elevated temperature. Wear 2009, 267, 1856-1864. [CrossRef]

10. Koga, G.Y.; Schulz, S.; Savoie, A.R.C.; Nascimento, Y.; Drolet, C.; Bolfarini, C.S. Microstructure and wear behavior of Fe-based amorphous HVOF coatings produced from commercial precursors. Surf. Coat. Technol. 2017, 309, 938-944. [CrossRef]

11. Kim, J.K.; Kim, G.M.; Kimv, S.J. The effect of manganese on the strain-induced martensitic transformation and high temperature wear resistance of Fe-20Cr-1C-1Si hardfacing alloy. J. Nucl. Mater. 2001, 289, 263-269. [CrossRef]

12. Aghili, S.E.; Enayati, M.H.; Karimzadeh, F. Synthesis of $(\mathrm{Fe}, \mathrm{Cr})_{3} \mathrm{Al}-\mathrm{Al}_{2} \mathrm{O}_{3}$ nanocomposite through mechanochemical combustion reaction induced by ball milling of $\mathrm{Cr}, \mathrm{Al}$ and $\mathrm{Fe}_{2} \mathrm{O}_{3}$ powders. Adv. Powder Technol. 2014, 25, 408-414. [CrossRef]

13. Rizaneh, S.; Borhani, G.H.; Tavoosi, M. Synthesis and characterization of $\mathrm{Al}_{(}\left(\mathrm{Al}_{2} \mathrm{O}_{3}-\mathrm{TiB}_{2} / \mathrm{Fe}\right)$ nanocomposite by means of mechanical alloying and hot extrusion processes. Adv. Powder Technol. 2014, 25, 1693-1698. [CrossRef]

14. Modi, O.P.; Prasad, B.K.; Jha, A.K.; Deshmukh, V.P.; Shah, A.K. Effects of Material Composition and Microstructural Features on Dry Sliding Wear Behaviour of Fe-TiC Composite and a Cobalt-Based Stellite. Tribol. Lett. 2004, 17, 129-138. [CrossRef]

15. Zhang, X.H.; Ma, J.Q.; Fu, L.C.; Zhu, S.Y.; Li, F.; Yang, J.; Liu, W.M. High temperature wear resistance of Fe-28Al-5Cr alloy and its composites reinforced by TiC. Tribol. Int. 2013, 61, 48-55. [CrossRef]

16. Chen, J.M.; Hou, G.L.; Chen, J.; An, Y.L.; Zhou, H.D.; Zhao, X.Q.; Yang, J. Composition versus friction and wear behavior of plasma sprayed $\mathrm{WC}-(\mathrm{W}, \mathrm{Cr})_{2} \mathrm{C}-\mathrm{Ni} / \mathrm{Ag} / \mathrm{BaF}_{2}-\mathrm{CaF}_{2}$ self-lubricating composite coatings for use up to $600{ }^{\circ} \mathrm{C}$. Appl. Surf. Sci. 2012, 261, 584-592. [CrossRef]

17. Essa, F.A.; Zhang, Q.X.; Huang, X.J. Investigation of the effects of mixtures of $\mathrm{WS}_{2}$ and $\mathrm{ZnO}$ solid lubricants on the sliding friction and wear of M50 steel against silicon nitride at elevated temperatures. Wear 2017, 374-375, 128-141. [CrossRef] 
18. Serra, E.C.; Soares, V.F.D.; Fernandez, D.A.R.; Hübler, R.; Juste, K.R.C.; Lima, C.L.; Tentardini, E.K. Influence of $\mathrm{WS}_{2}$ content on high temperature wear performance of magnetron sputtered TiN-WS $x$ thin films. Ceram. Int. 2019, 45, 19918-19924. [CrossRef]

19. Song, J.P.; Valefi, M.; Rooij, M.; Schipper, D.J.; Winnubs, L. The effect of an alumina counterface on friction reduction of $\mathrm{CuO} / 3 \mathrm{Y}-\mathrm{TZP}$ composite at room temperature. Wear 2012, 274-275, 75-83. [CrossRef]

20. Zhang, X.H.; Cheng, J.; Niu, M.Y.; Tan, H.; Liu, W.M.; Yang, J. Microstructure and high temperature tribological behavior of $\mathrm{Fe}_{3} \mathrm{Al}-\mathrm{Ba}_{0.25} \mathrm{Sr}_{0.75} \mathrm{SO}_{4}$ self-lubricating composites. Tribol. Int. 2016, 101, 81-87. [CrossRef]

21. Li, Y.F.; Ouyang, J.H.; Sasaki, S. Tribological properties of spark-plasma-sintered $\mathrm{ZrO}_{2}\left(\mathrm{Y}_{2} \mathrm{O}_{3}\right)-\mathrm{Al}_{2} \mathrm{O}_{3}-\mathrm{Ba}_{x} \mathrm{Sr}_{1-x} \mathrm{SO}_{4}(x=0.25,0.5,0.75)$ composites at elevated temperature. Tribol. Lett. 2012, 45, 291-300. [CrossRef]

22. Cui, G.J.; Lu, L.; Wu, J.; Liu, Y.P.; Gao, G.J. Microstructure and tribological properties of Fe-Cr matrix self-lubricating composites against $\mathrm{Si}_{3} \mathrm{~N}_{4}$ at high temperature. J. Alloys Compd. 2014, 611, 235-242. [CrossRef]

23. Cui, G.J.; Kou, Z.M. The effect of boron on mechanical behavior and microstructure for Fe-Cr matrix alloy prepared by P/M. J. Alloys Compd. 2014, 586, 699-702. [CrossRef]

24. Liu, F.; Zhou, Y.; Zhang, X.Y.; Cao, W.F.; Jia, J.H. Tribological properties of $\mathrm{NiCr}-\mathrm{ZrO}_{2}\left(\mathrm{Y}_{2} \mathrm{O}_{3}\right)-\mathrm{SrSO}_{4}$ composites at elevated temperatures. Ceram. Int. 2016, 42, 12981-12987. [CrossRef]

25. Lou, M.; Alpas, A.T. High temperature wear mechanisms in thermally oxidized titanium alloys for engine valve applications. Wear 2019, 426-427, 443-453. [CrossRef]

26. Tripathi, K.; Gyawali, G.; Lee, S.W. Graphene coating via chemical vapor deposition for improving friction and wear of gray cast iron at interfaces. ACS Appl. Mater. Interfaces 2017, 9, 32336-32351. [CrossRef]

27. Erdemir, A. A crystal-chemical approach to lubrication by solid oxides. Tribol. Lett. 2000, 8, 97-102. [CrossRef]

28. Li, B.; Gao, Y.M.; Han, M.M.; Guo, H.J.; Wang, W.J.; Jia, J.H. Microstructure and tribological properties of NiCrAlY-Mo-Ag composite by vacuum hot-press sintering. Vacuum 2017, 143, 1-6. [CrossRef]

29. Li, F.; Cheng, J.; Zhu, S.Y.; Hao, J.Y.; Yang, J.; Liu, W.M. Microstructure and mechanical properties of Ni-based high temperature solid-lubricating composites. Mater. Sci. Eng. A 2017, 682, 475-481. [CrossRef]

30. Valefi, M.; Rooi, M.j.; Schipper, D.J.; Winnubst, L. Effect of temperature on friction and wear behaviour of CuO-zirconia composites. J. Eur. Ceram. Soc. 2012, 32, 2235-2242. [CrossRef]

31. Radu, I.; Li, D.Y.; Llewellyn, R. Tribological behavior of Stellite 21 modified with yttrium. Wear 2004, 257, 1154-1166. [CrossRef] 